\title{
The Influence of Promotion via LINE Messenger on the Attitude of Starbucks' LINE Official Account Followers
}

\author{
Vira Dessy Arisandi; Santi Delliana ${ }^{2 *}$ \\ ${ }^{1,2}$ Communication Department, Kalbis Institute \\ Jl. Pulomas Selatan Kav. No. 22, RT. 4/RW. 9, Pulo Gadung, Jakarta Timur 13210, Indonesia \\ 1virada467@gmail.com; ${ }^{2}$ anastasia.santi@kalbis.ac.id
}

Received: $18^{\text {th }}$ November 2020/ Revised: $01^{\text {st }}$ February 2021/ Accepted: $01^{\text {st }}$ February 2021

\begin{abstract}
How to Cite: Arisandi., V. D. \& Delliana, S. (2020). The influence of promotion via LINE messenger on the attitude of Starbucks' LINE official account followers. The Winners, 21(2), 155-161.

https://doi.org/10.21512/tw.v21i2.6812
\end{abstract}

\begin{abstract}
The research aimed to determine the effect of promotion through persuasive messages via LINE messenger applications on the attitude of Starbucks' LINE official account followers. The analytical research applied the S-R (StimulusResponses) theory with quantitative approaches and survey methods by distributing questionnaires in analytical to 400 respondents, who are followers of Starbucks' LINE official account. The research uses sociopsychological tradition focusing on individual social behavior, personal effects, perception, cognition, personality and traits. Research findings were based on the answers of respondents who strongly agree on cognitive, contextual, and affective indicators. The research comes up with results indicating that there is a strong influence of promotion via LINE messenger on the attitude of Starbucks' LINE followers, where the magnitude is positive. The results find that customers receive Starbucks' promotion messages with positive attitudes and feedbacks as well. It is suggested that future research consider to determine the occurrence of stages of customers' purchase decision.
\end{abstract}

Keywords: online promotion, follower attitudes, LINE messenger

\section{INTRODUCTION}

Society relies on the internet and technology, making the internet increase in public affairs, such as economics, education, and entertainment media. It is considered easy and convenient for users who want to live fast and instant. They use hi-tech smartphones, tablets, laptops, and other devices. Previously sending and receiving messages can only be done via Short Message Service (SMS), whereas nowadays people send messages through social media such as WhatsApp, LINE, Facebook, Instagram, etc. With social media, it tends to be easier for users to get information to shop. The total number of active social media users in Indonesia is 150 million, and the percentage of the total population is $56 \%$. The total population in Indonesia is 268,2 million, according to data provided by We Are Social (Kemp, 2019).

Social media may be referred to in Rulli (2017) as an information collection or place used by its users. The information is like a commodity that can be exchanged, produced, and distributed by users. With the number of growth and users, social media exists to entertain the community and help communicate with other cities efficiently without distance restrictions. The results show that the promotion of LINE Starbucks social media influences consumer purchasing decisions in Jakarta, with $50,3 \%$ for the variables studied. At the same time, other variables influence the rest. (Engriani, Fitriana, \& Cetty, 2019).

Some companies also use various social media to promote their products and services. If the target market is the millennial generation, social media is considered very influential. Millennial generations grow alongside modern technology, so social media becomes the primary medium for accessing information. The coffee consumption of Indonesian people tends to increase over the past few years. Nowadays, drinking coffee tends to be a lifestyle where someone can spend time having fun (Lesmana, 2019). Many companies are now choosing to use social media as one of the promotional media. It is because more affordable and effective cost can reach all people without geographical and time constraints. Consumers can quickly get information about the product or service (Martinus \& Anggraini, 2018).

The research discusses the LINE messenger's involvement as a medium to disseminate persuasive messages by promoting Starbucks' LINE official 
account. According to the Indonesian Dictionary (KBBI), the meaning of convincing is to persuade people to do something. Buyers should be able to select their products (in this case, a smartphone), but customers should change their purchasing decisions precisely due to a persuasive message (Rakhman, 2019). Promotional activities seem to be increasingly important and necessary today. This is due to the distance that has increased between producers and consumers, the number of potential customers, and intermediaries' presence (Syam \& Rachman, 2019).

According to Jenkis in Rulli (2017), several media industry sectors have engaged active viewers as an extension of their marketing, which of course, is to get more meaningful feedback from their fans. They work closely with the audience to produce content and design processes.

One aspect which develops from marketing or marketing in the era of media social is persuasive in time or space or use mass media by institutions business, organization non-profit, government or individuals to inform and persuade the public to goods, services, organizations, ideas as a target, target marketing or audience (Rulli, 2017).

According to Ramadanty and Widayanti (2020), research results show high positive relationship between sales promotion and brand loyalty through LINE official account. The rapid growth of social media development leads to great brands' advertising for their products or services (Tjandrawibawa, 2020).

Starbucks is the biggest tavern coffee in the world. The first Starbucks in Indonesia was opened at Mall Plaza Indonesia on May $17^{\text {th }}, 2002$. This coffee shop has 326 branches in 22 cities in Indonesia. Starbucks is in the eighth position on the official
LINE account rank as the most widely followed by Indonesian people. There were 8.500.829 followers tracked on Starbucks' LINE official account on September $23^{\text {rd }}, 2019$. They get persuasive personal messages or e-coupons exchanged at Starbucks outlets throughout Indonesia every day.

In addition to Starbucks, several compositors are food and beverage companies that join LINE official accounts, such as Excelso and Dunkin' Donuts. Figure 1 shows examples of broadcast messages by Starbucks' LINE official account: 1) E-coupons or vouchers that can be exchanged directly at Starbucks outlets; 2) persuasive messages such as Buy 1 Get 1 Free, discount up to $50 \%$, and special price discounts for specific dates to customers who bring Starbucks official drinking bottles. Based on research by Romdhoni, Hasiholan, and Amboningtyas (2020), it can be concluded that the respondents are aware of what Starbucks is doing, which in the research discusses green products, green promotion, green processes, green physical evidence, and almost positive perceptions expressed by respondents towards all the marketing mix.

With more than eight million followers on the Starbucks' LINE and persuasive messages they have broadcasted to the followers, the research aims to find whether there is any consideration for potential customers and the influence that Starbucks give to people. These vouchers are given a date determined by Starbucks' LINE to be valid for only one to two days since it is distributed to the followers. One example of a message for one week can be seen in Figure 1, in which messages always start with phrases that make customers feel special and lucky.

The program is made for entertainment and

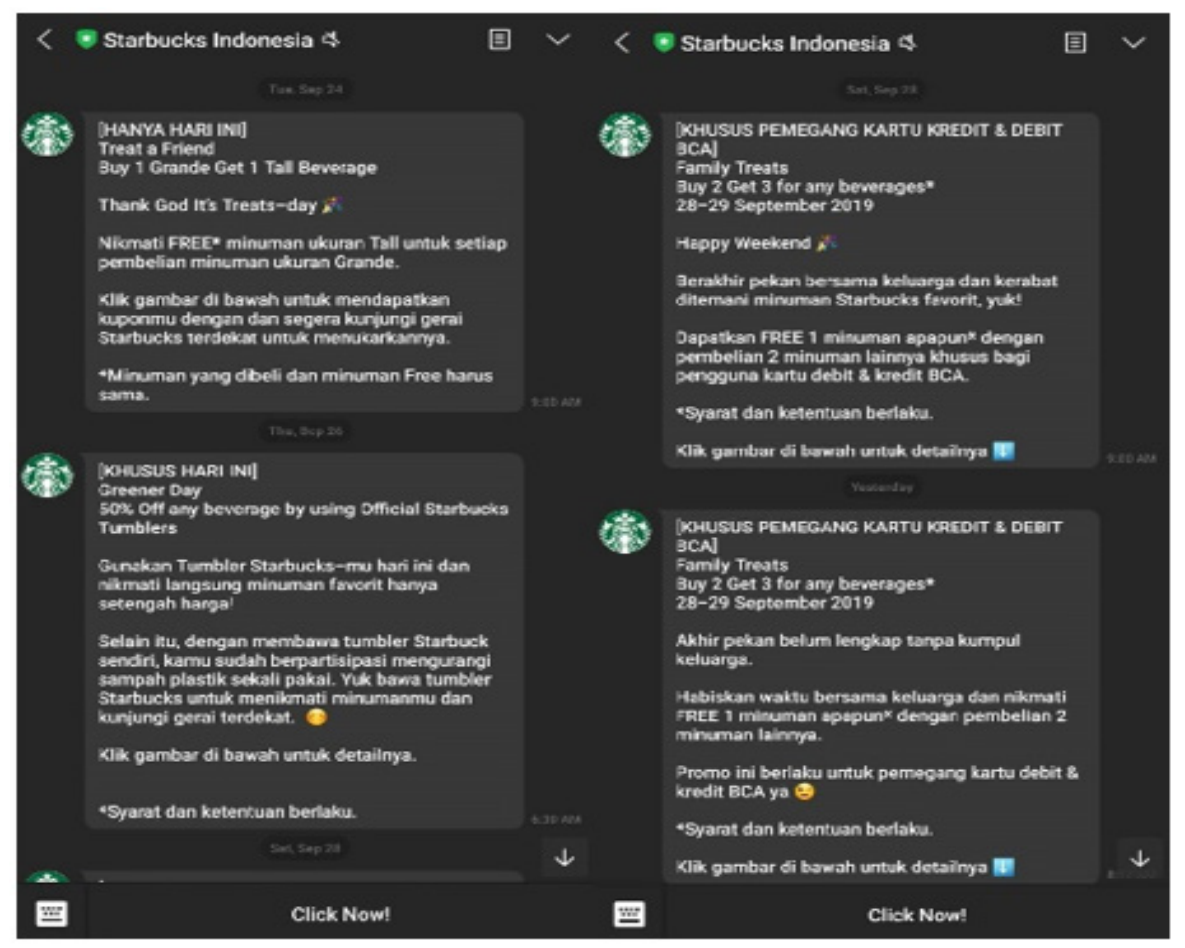

Figure 1 Persuasive Messages on the Starbucks' LINE Official Account 
commercial purposes, so persuasive objective can change the meaning of the program and the brands in the context of brand placement. This shift can lead to detachment and resistance in turn (Boerman et al., 2020). Therefore, it can be said that persuasive communication affects increasing the income of affiliate marketers through affective and conative cognitive applications (Hereyah \& Hutajulu, 2021). According to Aruan et al. (2020), as a reference in organizing an event and using technological developments and digitalization to maximize publication to obtain maximum publicity, Miniso can use the Nine Steps of Strategic Public Relations.

According to Mulyana (2017), the S-R (stimulusresponse) theory is the most basic communication model influenced by psychological disciplines, specifically behavioristic flow. The method illustrates the existence of a stimulus-response relationship.

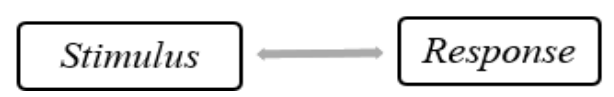

Figure 2 Stimulus - Response Theory Source: Mulyana (2017)

Figure 2 explains that the S-R theory shows communication as a straightforward action-reaction process. This theory's assumptions are verbal, nonverbal words, pictures, and specific actions that can stimulate others to respond in certain ways. This process can be reciprocal with many effects, each of which can change the next communication action.

The S-R theory is useful for the research as it aims to look for promotional messages on the followers' attitudes of Starbucks' LINE. The aspect used as a stimulus is a promotional message in LINE messenger application. The element used as a response in the research is the followers' attitude of Starbucks' LINE official account. That is how the stimulus of a promotional message can affect the position of followers.

\section{METHODS}

The research paradigm is positivism, which is counted on the philosophical stance of natural scientists working with observable reality within society, leading to generalizations (Alharahsheh \& Pius, 2020). The characteristics of the science of positivism are: 1) Objectivism, which means theories about the universe must have freedom of values; 2) Phenomenalism, namely science, only talks about the observed universe; 3 ) Reductionism, i.e., the universe is reduced to observable facts; 4) Naturalism, namely the universe, are objects that move mechanically (Bungin, 2017).

The research uses a quantitative approach to the type of analytical research. The quantitative approach views human behavior as a predictable and social reality, objective, and measurable. Therefore, quantitative research with valid and reliable instruments and appropriate statistical analysis causes the research results not to deviate from the actual conditions. In identifying the problem, to formulate them is the first and most critical stage of the study, as problem formulation guides all research courses. The researcher will lose direction in researching without exact problem wording (Ridha, 2017). One of the key characteristics of research using a quantitative approach is statistical analysis (Ridha, 2017). Explanation level research aims to explain the variables by fiber's influence or compare one variable with another variable. One explanation level has been grouped, focusing on associative research or relationships, where the research aims to determine the relationship between two or more variables (Siregar, 2013).

The research uses survey method. According to Kerlinger in Siregar (2013), there are several characteristics of survey research: 1) the research object is conducted on large and small populations, where the data are samples taken from the total population; 2) survey research is carried out to generalize in-depth observations; and 3) the survey method does not require a control group, so does the experimental approach.

The research uses explanation since it focuses on finding the causal relationship between the independent variables and the dependent variable. According to Siregar (2013), research that aims to explain the position of the variables studied and the influence or compare between one variable with other variables, one of which is grouped explanations while focusing on associative or relationship. Whereas the research aims to determine the relationship between two or more variables.

The operational definition writing technique is to write a formula that states a decrease in concepts to practical standards, clear criteria, and does not raise hypothetical new questions. The following are operational variables for measuring variables in the research:

Variable X: Promotion in the LINE messenger application

Variable Y : Starbucks LINE official account followers' attitude

Although the data are collected from a representative population (sample), generalizations are always emphasized (Ridha, 2017). As a result, data collection activities are best entrusted to instruments (including field data collectors). The research uses the non-probability sampling technique, which is random sampling by collecting many of the population whose results are drawn to several sample by Slovin formula (Bungin, 2017).

Sampling is taken from among Starbucks' LINE official account followers. Sample of the research uses 
the Slovin formula (Siregar, 2013). The calculation is provided:

$$
\begin{aligned}
\mathrm{n} & =\frac{8500829}{1+(8500829)(0.05)^{2}} \\
\mathrm{n} & =\frac{8500829}{1+(8500829)(0.0025)} \\
\mathrm{n} & = \\
\mathrm{n} & =\frac{\frac{8500829}{1+21252,07}}{21253,07} \\
& =399,98 \text { rounded off to } 400
\end{aligned}
$$

Thus, based on the calculation, the samples are 400 respondents on Starbucks' official account followers. The data are obtained from a survey method with a questionnaire filled out by respondents, those are adolescents who have joined Starbucks' LINE official account. In the research, Google forms are filled in by respondents.

\section{RESULTS AND DISCUSSIONS}

Correlation analysis is used to determine whether there is a relationship between two variables to determine the level of connection between the independent variable and the dependent variable, where: 1) Independent variable (X) is 'promotion influence on LINE messenger applications'; and 2) Dependent variable $(\mathrm{Y})$ is 'the attitude of Starbucks' LINE account followers'. The correlation value is Pearson's Correlation in Product Moment.

Questionnaires are processed using IBM SPSS Statistics for Macbook to come up with the results, as seen in Table 1, showing that the significance value of the independent variable $(\mathrm{X})$ with the dependent variable $(\mathrm{Y})$ of 0,000 , where the amount is smaller than the significance value of 0,05 which means there is a relationship. Thus, it can be concluded that there is a relationship between the independent variable $(\mathrm{X})$ to the dependent variable (Y). Based on the explanation of the relationship's strength, the value of $r$ on the correlation between the independent variable (X) and the dependent variable $(\mathrm{Y})$ is 0,747 , where the cost is in the middle of the relationship. Thus, there is a moderate and positive relationship, which means that the link's form is unidirectional. If variable $\mathrm{X}$ rises, then variable $\mathrm{Y}$ also rises.

After identifying the relationship's strength, the process continues to analyse the regression to predict how much dependent and independent variables will fluctuate. It is known constants from the results of the regression analysis between the influences of Starbucks' LINE promotion (X) with attitudes of Starbucks' LINE followers (Y). The regression equation is obtained:

$\mathrm{Y}=\mathrm{a}+\mathrm{bX}$

$\mathrm{Y}=6,862+1,247 \mathrm{X}$

Information:

$\mathrm{Y}=$ Dependent variable (promotion in Starbucks' LINE)

$\mathrm{X}=$ Free variable (attitude of Starbucks' LINE followers)

$\mathrm{a}=$ constant value

$\mathrm{b}=$ Regression Coefficient

From the results listed, there is a regression between the independent variable and dependent variable, i.e. $\mathrm{Y}=6,862+1,247 \mathrm{X}$. It can be concluded that each increase in score on the influence of Starbucks' LINE promotion (X) will be followed by the rise in the rating of attitudes of Starbucks' LINE followers (Y) by 1,247 in the positive direction with a constant of 6,862 . Thus, the dependent variable and independent variable simultaneously decrease since the independent variable has a strong influence on the dependent variable. In other words, promotion on LINE messenger has a strong effect on the attitude of Starbucks' LINE followers.

It comes up with the result that the contribution of promotion (X) to the attitude of Starbucks' followers (Y) variable is 0,558 or $55,8 \%$ in percentage, seen from the coefficient of determination in Table 1 is $R$ Square. Simultaneously, the rest is explained by other variables not taken into account in the research. Thus, it can be concluded that the effect of promotion via Starbucks' LINE on the attitude of Starbuck's official account followers is $55,8 \%$.

A t-test is performed to determine whether the promotion via LINE messenger affects Starbucks' LINE followers. For this reason, it is necessary to compare t-counts and t-tables using a two-tailed test and, in the research, using a significance level of $5 \%$.

Table 1 Dependent Variable: The Attitude of Starbucks' LINE Official Account Followers

\begin{tabular}{llccccc}
\hline & Model & \multicolumn{2}{c}{$\begin{array}{c}\text { Unstandardized } \\
\text { Coefficients }\end{array}$} & $\begin{array}{c}\text { Standardized } \\
\text { Coefficients }\end{array}$ & T & Sig. \\
\cline { 3 - 6 } & B & Std. Error & Beta & & \\
\hline 1 & (Constant) & 6,862 & 1,265 & & 5,423 & 0,000 \\
& $\begin{array}{l}\text { Effect of Promotion on the Messenger LINE } \\
\text { application }\end{array}$ & 1,247 & 0,056 & 0,747 & 22,421 & 0,000 \\
\hline
\end{tabular}


It is known that those social media variables have a $\mathrm{t}$-count value of 22,421, while the t-table value for 400 respondents is 1,966 with $\mathrm{df}=398$ is 0,05 . T-count is more significant than t-table, so it can be concluded that $\mathrm{H}_{0}$ is rejected, and $\mathrm{H}_{1}$ is accepted.

The following decision making for hypothesis testing using t-test:

If $\mathrm{t}$-count $>\mathrm{t}$-table $=\mathrm{H}_{0}$ is rejected and $\mathrm{H}_{1}$ is accepted If $\mathrm{t}$-count $<\mathrm{t}$-table $=\mathrm{H}_{0}$ is accepted and $\mathrm{H}_{1}$ is rejected

It is concluded that there is the influence of promotions through LINE messenger on the attitude of Starbucks' LINE followers.

In the research, the author uses the sociopsychological tradition, which focuses on individual social behavior, social-psychological, personal effects, personality and traits, perception, and cognition. The three branches of essential aspects in the sociopsychological tradition are behavior, awareness, and biology.

S-R theory is used as the leading theory since it is considered the most appropriate methods to describe the effect of the message content in LINE messenger on Starbucks' LINE followers by focusing on the stimulus and response elements.

In the research, two critical elements in the S-R theory are: 1) Stimulus - fill the message in the Messenger LINE application, incentive in the form of persuasive words broadcasted daily such as new beverage products, buy one get one free, and accept both more economically; and 2) Response-the response or expected effect in the research is a change in attitude toward behavior.

The S-R theory considers communication as a smooth reaction-action. In social media, S-R theory believes that social media has a strong power to influence social media users with a visible stimulus. Using SPSS, the followers agree that persuasive messages by Starbucks' LINE are strongly influential.

According to Ritonga (2005), persuasive messages are considered one way to divert ideas and actions by organizing motives into specific goals. Promotion via LINE messenger seems to be Starbucks' purpose to reach customers since it is one of the effective ways to spread persuasive messages more personally. According to Severin and Tankard, Jr (2001), there are five information-processing theory ways. First, the persuasive message must be communicated. Starbucks spreads message about their new menus or discounts. Second, the message recipient will pay attention to the news as Starbucks shares them personally. Third, the recipients will understand the messages. Fourth, the recipient is influenced and convinced by the information presented. Furthermore, from the SPSS calculation, the result shows that followers are affected by words in the broadcasted messages from Starbucks' LINE. Fifth, there is the desired behavior to attract attention and buy products from Starbucks. In the research, the persuasive message model is psychodynamic, a compelling message, and alternative latent psychological processes such as motivation, attitude, and changes in the desired form.

The results also show that between LINE social media (variable $X$ ), and persuasive messages (variable Y), there is a reasonably healthy positive relationship. This is indicated by Pearson's Product Moment correlation coefficient of 0,747 . Due to the sufficiently healthy relationship between variables $\mathrm{X}$ and $\mathrm{Y}$, promotion on LINE messenger and the followers' attitude will go simultaneously, whether it is an increase or a decrease.

The results of simple linear regression analysis shows that each increase in score on the effect of promotion on LINE messenger will be followed by the attitude of Starbucks' followers by 1,247 in the direction of upbeat with a constant 6,862 . These results also explain that the S-R theory can show promotion in LINE messenger. On the questionnaire results, there are details of the respondent's answers to variable $\mathrm{X}$ statements, that is, statements considered to be the effect of the message content in the LINE messenger to influence Starbucks' followers. The results can be categorized as the strongest or weakest results. The lowest result with a 1.220 score is that an order via Starbucks' LINE is enough to convince customers to buy the product.

On the other hand, some results are considered the strongest among the other products. There are two most main statements that customers respond to, namely: 1) Customers receive personalized promotional messages directly from Starbucks' LINE; 2) Starbucks always posts information about new products and vouchers/coupons every day in their timeline.

The following results get the most significant percentage, which means $100 \%$ of respondents strongly agree. Firstly, respondents have not only received information Starbucks' LINE official account, but also from other sources. Second, 236 out of 400 respondents do not feel disturbed by continuously receiving LINE messages from Starbucks. Thirdly, 94 out of 400 respondents agree that the perfect time for Starbucks to send messages is around 7 to 8 in the morning to share its compelling message.

Many strongly agree with the ten promotional indicator statements in LINE messenger, including open questionnaires that are considered a promotional influence on LINE messenger, signifying that Starbucks' followers have received persuasive messages. The approach intended in the research is measured using three indicators, which include cognitive effects, affective effects, and behavioral effects.

Questionnaire results for the attitude of Starbucks' followers show that out of a total of 11 statements, all of them are dominated by answers that strongly agree. Based on the $\mathrm{Y}$ variable questionnaire results, the stimulus has successfully influenced respondents to a behavioral level. The result is according to most respondents, who strongly agree with cognitive, affective, and behavioral indicators.

Cognitively, respondents tend to agree that the 
contents of messages from Starbucks' LINE official account affect knowledge about new products and discount coupons, which tend to influence their feelings. Most respondents strongly agree with the indicators of telling, persuading, and reminding as respondents are happy and satisfied with Starbucks' promotion as well as their themed picture messages (important national and international days). Respondents often await words given on Starbucks' LINE official reports. On behavioral indicators, Starbucks' LINE official account can affect respondents' attitude changes, such as when respondents only buy menus on discount with the acquisition of strongly agree is 122 respondents and agree is 106 respondents, out of 400 respondents. Moreover, 187 respondents strongly agree and 125 of them agrees that they purchase Starbucks' latest variant.

In the last statement, 206 respondents strongly agree and 91 of them agree that they would prefer buy products after receiving discount messages from Starbucks compared to discount from other cafes' LINE accounts. From the results of the Y variable, promotion on LINE messenger can affect respondents' attitude changes. This is compatible with the findings of questionnaire variable $\mathrm{X}$ that respondents agree with the statement. In other words, there is an effect of promotions on LINE messenger towards the attitudes of Starbucks' LINE official account followers.

The research provides results with percentages. Out of 400 respondents, 331 or $82,75 \%$ of them gets information from other sources beside Starbucks' LINE. As many as $84,60 \%$ of respondents purchase the latest taste variant, as well as agree that the perfect time to share promotion messages is around 7 to $8 \mathrm{AM}$. Meanwhile $94,35 \%$ of them is interested in the news and visuals added compulsively to Starbucks products. Lastly, $100 \%$ of respondents are happy when Starbucks shares persuasive messages with specific themes on both national and international holidays.

\section{CONCLUSIONS}

The data processing results of promotion messages via LINE messenger (variable $\mathrm{X}$ ) and the attitude of Starbucks' LINE official account followers (variable Y) can be concluded based on the information collection, data processing, and discussion that the respondents strongly support all statements.

The hypothesis test results show a significant effect of 0,000 , which is substantial if the products are smaller than 0,05 . The correlation test results also show a positive correlation of 0,747 between promotions on LINE messenger to the attitudes of Starbucks' LINE official account followers.

Based on the regression analysis results of $\mathrm{Y}=6,862+1,247 \mathrm{X}$, any increase in score on LINE messenger will go simultaneously with the score on the attitude of Starbucks' LINE followers by 1,247 with a constant of 6,862. Moreover, it is known that the magnitude of its impact through the coefficient of determination equal to $55,8 \%$. Thus there is a promotional influence on LINE messenger towards attitudes of Starbucks' LINE followers with a healthy relationship level of $55,8 \%$, while $44,2 \%$ is influenced by other variables not explained in the research.

Compared to the timeline posts of Starbucks' LINE official account, it is expected that the research can be an input for Starbucks in sharing its persuasive messages at the suggested times - 7 to $8 \mathrm{AM}$ - to share notes through chat rooms. It is possible that chat rooms are more comfortable to read than timeline posts. The AIDA (attention, interest, desire, and action) theory can be used for future research to determine the stages that occur when customers are aware to decide to purchase a product.

\section{REFERENCES}

Alharahsheh, H. H., \& Pius, A. (2020). A review of fundamental paradigms: Positivism VS interpretivism. Global Academic Journal of Humanities and Social Sciences, 2(3), 3943. ht https://www.gajrc.com/media/articles/ GAJHSS 23 39-43.pdf.

Aruan, A. M., Tiffany, V., Rahmadilla, S. K., \& Delliana, S. (2020). Implementation of special event strategy supporting brand awareness of Miniso beauty product. Solid State Technology, 63(1), 1. http:// www.solidstatetechnology.us/index.php/JSST/ article/view/526.

Boerman, S. C., Tessitore, T., \& Müller, C. M. (2020). Long-term effects of brand placement disclosure on persuasion knowledge and brand responses. International Journal of Advertising: The Review of Marketing Communications, 1-23. https://doi.org/10 .1080/02650487.2020.1775036.

Bungin, M. B. (2017). Metode Penelitian Kuantitatif: Komunikasi, Ekonomi, dan Kebijakan Publik Serta Ilmu-Ilmu Sosial Lainnya. Jakarta: Kencana Prenada Media Group.

Engriani, M., Fitriana, R., \& Cetty. (2019). Pengaruh promosi media sosial Line terhadap keputusan pembelian di Starbucks Mall Taman Anggrek. Jurnal IKRA-ITH Ekonomika, 2(3), 140-147. http://journals.upi-yai. ac.id/index.php/IKRAITH-EKONOMIKA/article/ download/662/502.

Hereyah, Y. \& Hutajulu, N. (2021). The effect of persuasive communication of affiliate marketers on increasing Viva product sales on Beliviva.Com (cognitive, affective, and conative application survey). Solid State Technology, 64(2). http://www.solidstatetechnology. us/index.php/JSST/article/view/8859.

Kemp, S. (2019, January 31). Digital 2019: Indonesia. Datareportal. https://datareportal.com/reports/ digital-2019-indonesia.

Lesmana, T. (2019). Karakteristik kepribadian, harga diri dan gaya hidup hedonisme pada mahasiswa konsumen Starbucks. Jurnal Ilmu Perilaku, 3(1), 59-71. https://doi.org/10.25077/jip.3.1.59-71.2019.

Martinus, H. \& Anggraini, L. (2018). The effect of sales 
promotion in social media on the students: Purchase intention of face cleaner water product. Humaniora Journal, 9(1), 15-22. https://doi.org/10.21512/ humaniora.v9i1.410.

Mulyana, D. (2017). Ilmu Komunikasi Suatu Pengantar (Revisi). Jakarta: Remaja Rosdakarya.

Rakhman, A. K. (2019). Strategi persuasi salesperson Oppo dalam menawarkan produk kepada konsumen. Mozaik Komunikasi, 1(1), 1-12. http://jom.untidar. ac.id/index.php/mozaik/article/view/711.

Ramadanty, S. \& Widayanti, R. (2020). Sales promotion and brand loyalty through mobile application Line official account. Journal of Critical Reviews, 7(17), 1720-1727. http://www.jcreview.com/?mno=39510

Ridha, N. (2017). Proses penelitian, masalah, variabel dan paradigma penelitian. Jurnal Hikmah, 14(1), 62-70. http://jurnalhikmah.staisumatera-medan.ac.id/index. $\mathrm{php} / \mathrm{hikmah} / \mathrm{article} / \mathrm{view} / 18$.

Ritonga, M. J. (2005). Tipologi Pesan Persuasif. Jakarta: Indeks.

Romdhoni, M., Hasiholan, L. B., \& Amboningtyas, D. (2020). An awareness and analysis consumer perception of application of green marketing Starbucks (Case study at Starbucks in Java Mall
Semarang). Journal of Management, 6(6). http:// jurnal.unpand.ac.id/index.php/MS/article/view/1517

Rulli, N. (2017). Media Sosial. Bandung: Simbiosa Rekatama Media.

Siregar, S. (2013). Metode Penelitian Kuantitatif: Dilengkapi dengan Perbandingan Perhitungan Manual \& SPSS. Jakarta: Kencana Prenada Media Group.

Severin, W. J. \& Tankard, Jr. J. W. (2001). Communication Theories: Origins, Methods and Uses in the Mass Media ( $5^{\text {th }}$ Ed.). Austin: Pearson.

Syam, S. \& Rachman, S. (2019). Strategi pemasaran sepeda motor Suzuki melalui promosi penjualan pada PT Sinar Galesong Mandiri cabang Urip Sumoharjo Makassar. Jurnal Ekonomi Balance Fakultas Ekonomi dan Bisnis, 15(2), 213-233. https://doi. org/10.26618/jeb.v15i2.2192.

Tjandrawibawa, P. (2020). The effect of using Instagram influencers in building Conseva's brand awareness. The Winners, 21(1), 67-73. https://doi.org/10.21512/ tw.v21i1.6497. 